\title{
Efektivitas Cognitive Behavioral Group Therapy berbasis Daring dalam Meningkatkan Self Esteem pada Mahasiswa yang Mengalami Kecemasan dalam Upward Social Comparison
}

\section{Effectivity Online Cognitive Behavioral Group Therapy to Enhance Self Esteem among College Students with Anxiety in Upward Social Comparison Context}

\author{
Hidayati, Fivi Nurwianti \\ Fakultas Psikologi Universitas Indonesia \\ Email: hidayati81@ui.ac.id; fivi-n@ui.ac.id
}

KATA KUNCI $\quad C B T$, Kecemasan, Self Esteem, Upward Social Comparison.

KEYWORDS $\quad$ CBT, Anxiety, Self Esteem, Upward Social Comparison.

ABSTRAK Kecemasan merupakan masalah yang umum terjadi pada kelompok mahasiswa. Meskipun pada dasarnya cemas merupakan respon yang adaptif, namun jika cemas berlebihan akan mengganggu performa dari seseorang. Cemas dapat muncul di berbagai situasi yang dipersepsi mengancam dan penuh dengan ketidakpastian, salah satunya pada konteks social comparison. Individu membandingkan dirinya dan melihat orang lain lebih baik sehingga menimbulkan persepsi negatif terhadap diri. Saat orang lain dipersepsi lebih baik maka muncul rasa inferior yang menyebabkan rendahnya self esteem. Desain penelitian menggunakan model pre-post dan dilanjutkan dengan sesi follow up. Intervensi dilakukan sebanyak enam kali pertemuan. Penelitian ini menggunakan CBT kelompok dengan metode daring karena dapat menjangkau partisipan yang berada daerah yang berjauhan. Terdapat enam orang partisipan berpartisipasi dalam penelitian ini dan satu partisipan orang drop out di pertengahan sesi. Pendekatan kualitatif dan kuantitatif digunakan untuk menganalisis hasil. Perhitungan secara deskriptif menunjukkan peningkatan self esteem pada tiga orang partisipan yang diiringi dengan menurunnya gejala kecemasan. Secara kualitatif hasil menunjukkan bahwa CBT kelompok dengan metode daring cukup efektif dalam meningkatkan self esteem. Pada partisipan yang tidak mengalami penurunan kecemasan, kemungkinan disebabkan oleh faktor lain seperti trait maupun kondisi sulit lain yang dihadapi oleh partisipan saat ini. Penggunaan intervensi CBT kelompok dengan metode daring cukup menjanjikan dan dapat mempertemukan partisipan dengan masalah yang sama yang tinggal di area yang berjauhan. Dalam pelaksanaan secara daring terdapat beberapa hal yang diperhatikan seperti koneksi internet, interaksi antar, partisipan, dan membangun rapport dengan menggunakan aplikasi yang memfasilitasi terjadinya interaksi. 
ABSTRACT Anxiety is a common problem that usually happens in a group of a university student. Basically, anxiety is an adaptive response, but excessive anxiety will interfere with performance. Anxiety can appear in many situations that are perceived as threatening and uncertainty, one of which is in the comparison of social contact. Individuals compare themselves and see other people are better than themselves. Thus, it can cause a negative perception of themselves. When other people are perceived better then inferiority that can cause low self esteem will appear. Group CBT is designed to increase self esteem by reconstructing negative thoughts about oneself. The design of the research used the pre-post model then followed by a follow-up session. The intervention was done six meetings by using the CBT module, which has been adapted as needed and conducted online. Descriptive analysis shows that three participants have increase selfesteem and decrease anxiety symptoms. Qualitatively the result shows that it was quite effective to increase the self esteem of the three participants, which was followed by a decrease in anxiety symptoms. Those who did not get a decrease of anxiety probably caused by other factors that are currently facing by the participants, such as trait and difficult condition. Applying online CBT group is promising intervention method that could facilitated participant with same problems who live in various area. However, all the participants qualitatively reported that there is a change in a more positive mindset towards themselves. There are several things that should be concerned during the implementation, which are an internet connection, the interaction between participants, and building rapport using applications that facilitate interaction.

\section{PENDAHULUAN}

Berdasarkan pada artikel yang dilansir oleh Boston University Today (2016), kecemasan merupakan isu yang cukup penting di konteks akademik terutama pendidikan tinggi. Survei yang dilakukan oleh American College Health Association (ACHA) (2015) melaporkan bahwa sekitar $15,8 \%$ mahasiswa mengalami kecemasan. Kecemasan tersebut berdampak pada performa akademik. Di antara semua hal yang berkaitan dengan isu kesehatan mental sekitar 85,6\% merasa jenuh dengan rutinitas yang harus dilakukan dan sekitar 56,9\% merasa jenuh dengan akibat kecemasan. Meskipun demikian, banyak yang merasa takut untuk mencari pertolongan dalam rangka menghadapi kecemasannya. Di Indonesia tidak ada data khusus mengenai tingkat kecemasan pada mahasiswa secara umum. Meskipun demikian menurut riset kesehatan dasar (Kementrian Kesehatan RI,
2018), prevelensi berdasarkan usia masalah kesehatan mental pada kelompok usia 15-24 tahun adalah $6,2 \%$.

Pada dasarnya kecemasan merupakan reaksi alami tubuh untuk melakukan antisipasi terhadap bahaya dan ancaman di masa yang akan datang. Kecemasan merupakan hal yang adaptif pada tahap tertentu dimana akan meningkatkan kewaspadaan dan persiapan diri untuk menghindari situasi atau masalah yang berbahaya sebelum terjadi (Kring, Johnson, Davidson \& Neale, 2012). Kecemasan pada tahap tertentu juga dapat meningkatkan performa. Mellalieu, Hanton dan Jones (2003) menyatakan bahwa kecemasan yang positif akan menimbulkan rasa excitement dan mendorong untuk melakukan latihan, meningkatkan motivasi dan persiapan. Meski demikian, di sisi lain, kecemasan yang berlebihan dapat berdampak buruk pada performa, 
Kecemasan pada mahasiwa dapat dipicu oleh berbagai macam situasi. Corcker dan Luhtanen (2003, dalam Beiter, Nash, McCrady, Rhoades, Linscomb, Clarahan \& Sammut, 2014) menyatakan bahwa ketika memasuki perguruan tinggi, tekanan yang dialami mahasiswa turut meningkat diantaranya adanya tekanan akademis dan harus memenuhi target nilai tertentu, ujian, banyaknya materi yang harus dipelajari serta terkadang juga disebabkan oleh pengaturan waktu yang buruk. Dengan demikian, kecemasan dapat disebabkan oleh berbagai situasi tertentu.

Selain itu, peneliti melakukan survei mengenai penyebab kecemasan yang paling banyak terjadi di mahasiswa. Hasil survei menunjukkan sekitar $48,6 \%$ responden mengalami kecemasan karena membandingkan diri dengan orang lain (social comparison). Pemicu yang paling utama adalah saat mereka mengakses media sosial dan melihat pencapaian orang lain yang diunggah di halaman media sosial tersebut. Biasanya individu membandingkan untuk memastikan posisinya. Dalam hal ini, dilakukan dengan cara membandingkan diri dengan orang lain atau yang disebut dengan social comparison. Menurut Festinger (1954) individu membandingkan dirinya dengan orang lain ketika mereka tidak memiliki standar yang objektif. Individu yang kesadarannya lebih rendah dan merasa tidak memiliki keyakinan atas dirinya akan cenderung untuk melakukan social comparison. Menurut Wheeler dan Miyake (1992), social comparison berkorelasi dengan tingkat kepuasan hidup. Individu yang melakukan upward negative social comparison cenderung memiliki kepuasan hidup yang lebih rendah karena merasa gelisah. Rendahnya kepuasan hidup merupakan salah satu prediktor utama munculnya kecemasan (Mahmoud, Staten, Hall, \& Lennie, 2012). Selain itu, menurut Ladoucer, Gosselin dan Dugas (2000, dalam Butzer dan Kuiper, 2005) faktor lain yang memungkinkan social comparison terjadi adalah karena toleransi yang rendah terhadap situasi yang ambigu. Akibatnya mereka mengadopsi standar orang lain sebagai acuan untuk mengukur posisi mereka dalam rangka menurunkan perasaan ketidakpastian yang mereka alami.

Gibbon dan Buunk (1999, dalam Butzer dan Kuiper, 2005) menyatakan semakin tinggi motivasi untuk terlibat dalam social comparison maka akan semakin tinggi tingkat kecemasan yang dialami. Hal ini disebabkan karena adanya kekhawatiran terhadap hal-hal yang tidak dapat dikontrol di masa depan sehingga fokus akan beralih kepada evaluasi diri dengan cara membandingkan diri dengan orang lain serta pikiran akan hal buruk yang diprediksi akan muncul di masa yang akan datang. Festinger (1954) membagi social comparison menjadi dua bagian yaitu upward social comparison dan downward social comparison. Seseorang melakukan upward social comparison saat ia membandingkan diri dengan orang yang lebih baik dari dirinya, sedangkan downward social comparison terjadi saat individu membandingkan diri dengan orang yang berada pada level dibawahnya (Festinger, 1954). Adapun dampak dari upward social comparison lebih banyak menimbulkan munculnya perasaan negatif seperti perasaan iri dan merasa tidak setara dengan orang lain. Faktor lain yang memunculkan perasaan ini karena adanya keinginan untuk tampil lebih baik dibandingkan dengan orang lain. Oleh sebab itu, emosi negatif akan muncul saat melakukan upward social comparison dan merasa lebih baik saat melakukan downward comparison (Wheeler \& Miyake, 1992).

Dengan melakukan social comparison, akan menyebabkan seseorang seringkali melakukan evaluasi terhadap diri mereka sendiri. Downward comparison akan mendorong evaluasi positif dari diri karena merasa lebih baik dari orang yang dibandingkan. Di sisi lain upward social comparison sering kali menimbulkan evaluasi diri yang negatif sehingga berdampak pada menurunnya self esteem. Wheeler dan Miyake (1992) menyatakan bahwa cemas karena upward comparison, akan lebih sering dialami oleh orang dengan 
self esteem rendah. Hal tersebut dapat selfenhancement.

Saat memandang bahwa orang lain lebih kompeten, maka akan muncul perasaan inferior dan akan mengurangi kemampuan untuk mempersepsi informasi secara objektif (Brophy, 2005, dalam Micari \& Pazos, 2014). Micari dan Drane (2011) mengungkapkan bahwa mahasiswa yang fokus pada membandingkan diri dengan orang lain memiliki persistensi, nilai, dan efikasi diri yang lebih rendah karena memiliki masalah dengan rasa percaya diri. Selain itu, individu yang tidak yakin dan cemas mengenai performanya hanya fokus pada evaluasi negatif terhadap diri sendiri karena selalu berpikiran bahwa orang lain lebih baik dari dirinya (Micari \& Drane, 2011). Hal ini membuat individu mengalami kesulitan untuk mengapresiasi diri karena adanya pikiran yang tidak adaptif terhadap diri sendiri.

Berbagai teori menjelaskan bahwa self esteem merupakan faktor protektif terhadap kecemasan. (Crocker \& Park, dalam Sowislo \& Orth, 2013). Hasil dari meta-analisis menunjukkan bahwa terdapat hubungan timbal balik antara self esteem dengan kecemasan. Self esteem dapat memprediksi kecemasan dan begitupun sebaliknya. Individu dengan self esteem yang lebih rendah disebabkan oleh tingginya aspirasi namun tidak diimbangi dengan tingkat kompetensi sesuai. Hal ini menyebabkan adanya diskrepansi antara kondisi ideal dengan yang sebenarnya sehingga menyebabkan kecemasan dan depresi (Harter, 1993). Festinger (dalam Aspinwall dan Taylor, 1993) menyatakan social comparison tidak hanya dilakukan untuk mengevaluasi pendapat dari orang lain tapi juga untuk mengelola emosi dan mempertahankan self esteem. Individu yang memiliki pandangan yang lebih positif, mampu membela diri dan tidak terlalu terpengaruh oleh kritik yang dilontarkan oleh orang lain (Gilbert \& Miles, 2000).

Di sisi lain, Gilbert dan Miles (2000) menyatakan individu yang melihat dirinya secara negatif cenderung memiliki pandangan negatif terhadap diri dan mempersepsi bahwa orang lain juga berpikiran negatif terhadap diri mereka. Bentuk dari pikiran tersebut seperti, "Saya melihat diri saya tidak berdaya"; "Orang lain berpikir bahwa saya tidak berdaya". Hal ini pada mulanya dapat dipicu oleh kritikan yang dilontarkan oleh orang lain. Individu akan semakin menginternalisasi kritik tersebut jika yang memberi kritik adalah orang yang lebih superior. Hal tersebut memicu munculnya perasaan inferior dan membuat individu menyalahkan dirinya. Kondisi tersebut berdampak pada munculnya perasaan cemas, marah, dan sikap bermusuhan.

Berdasarkan pada fenomena tersebut, rasa cemas akibat social comparison berdampak negatif pada kondisi psikologis invidu. Terdapat indikasi rasa tidak puas dengan diri sendiri sehingga dapat berdampak pada performa akademi, rendahnya kepuasan hidup dan munculnya rasa putus asa. Peneliti terdorong untuk merancang dan melakukan intervensi untuk menurunkan kecemasan mahasiswa yang dipicu oleh social comparison sehingga dapat meningkatkan self esteem. Berdasarkan pada pemaparan di atas, social comparison lebih disebabkan oleh adanya pikiran yang tidak adaptif sehingga menyebabkan munculnya emosi dan cara pandang yang negatif terhadap diri sendiri. Adanya distorsi kognitif yang berdampak pada munculnya emosi negatif merupakan kekhasan dari kerangka teori Cognitive Behavioral Therapy (CBT). CBT memandang bahwa pola pikir tertentu dan sudut pandang melihat situasi akan mempengaruhi emosi yang muncul. Dengan kata lain, pemaknaan negatif terhadap kondisi akan memicu munculnya emosi negatif yang rentan terhadap distres psikologis.

Berdasarkan penelitian meta analisis yang dilakukan oleh Regehr, Glancy, dan Pitts (2013) mengungkapkan bahwa terapi kognitif perilaku (yang terdiri atas restruktur kognitif, relaksasi dan meditasi) memiliki dampak yang signifikan dalam mengurangi 
simtom kecemasan terhadap mahasiswa meskipun terdapat perbedaan jumlah sesi di berbagai prakteknya dan dapat meningkatkan self esteem (Soraya, 2016).

Banyak bukti yang menunjukkan bahwa CBT efektif dalam menangani masalah psikologis. Dengan perkembangan teknologi, saat ini telah banyak yang mencoba mengembangkan intervensi CBT individual secara langsung yang dikolaborasikan dengan metode daring. Cakupan metode daring yang dimaksud dalam penelitian sebelumnya hanya sekedar pemberian tugas dan pelaporan perubahan yang dirasakan oleh partisipan melalui surat elektronik sementara pemberian terapi dilakukan secara tatap muka. Hasil riset menunjukkan bahwa tidak terdapat perbedaan yang signifikan antara metode CBT berbasis internet dengan CBT yang dilakukan secara tatap muka (Barak, Hen, Nissim, \& Shapira, 2008; Kumar, Sattar, Bseiso, Khan, \& Rutkofsky, 2017). Meskipun demikian, belum ada studi sebelumnya yang meneliti mengenai efektivitas CBT dimana semua interaksi dilakukan secara daring dan melalui tatap muka secara virtual baik secara individu maupun kelompok.

Penggunaan teknologi dalam psikoterapi dapat memberikan berbagai keuntungan seperti hemat biaya dan dapat menjangkau partisipan yang berada di berbagai wilayah (Kumar dkk., 2017). Selain itu, metode daring juga sangat menguntungkan dan tidak menghambat berjalannya terapi terutama saat ada pembatasan fisik saat pandemi COVID 19 dimana pertemuan tatap muka tidak mungkin dilakukan.

Menurut Westbrook, Kennerley, dan Kirk (2011), secara umum prinsip dari CBT meliputi beberapa prinsip diantaranya (1) prinsip kognitif, dimana emosi sangat dipengaruhi oleh kognisi dengan kata lain makna yang diberikan terhadap suatu situasi; (2) prinsip perilaku, apa yang kita lakukan memiliki dampak besar terhadap pikiran, emosi, sehingga merubah perilaku; (3) prinsip here and now, fokus pada proses yang terjadi saat ini dibandingkan masa lalu; (4) interaksi dari berbagai sistem dimana pikiran, emosi, perilaku, fisiologi dan lingkungan saling berinteraksi terhadap individu.

Adapun tujuan dari intervensi ini adalah penerapan CBT adalah menurunkan kecemasan yang diakibatkan oleh social comparison sehingga dapat meningkatkan self esteem. Peneliti menduga bahwa dengan terapi kelompok CBT terdapat penurunan kecemasan akibat social comparison yang diikuti dengan meningkatnya self esteem pada partisipan.

\section{METODE PENELITIAN Pendekatan}

Penelitian ini merupakan penelitian eksperimen dengan metode pre-post design. Pengukuran dilakukan sebanyak empat kali, pre-test, pertangahan sesi, post-test dan sesi follow up setelah sesi dilakukan. Jumlah sesi yang diberikan sebanyak enam sesi dengan menggunakan aplikasi zoom yang berlangsung sekitar 90-110 menit.

\section{Partisipan}

Pemilihan partisipan dilakukan dengan metode convenience sampling. Sampel pada partisipan merupakan mahasiswa program sarjana Universitas X. Partisipan diperoleh dengan cara menyebarkan informasi beserta link pendaftaran mengenai intervensi kelompok mengenai kecemasan. Terdapat enam orang partisipan yang terpilih untuk berpartisipasi dalam penelitian ini. Rentang usia dari 18-21 tahun. Terdiri atas dua laki-laki dan empat orang perempuan. Sebagin besar berasal dari fakultas psikologi.

Partisipan memiliki skor kecemasan yang diukur dengan alat ukur State Trait Anxiety Inventory (STAI) dengan skor $\geq 40$. Sebanyak 6 orang partisipan dihubungi untuk mengikuti sesi. Terdapat satu partisipan yang memutuskan keluar karena merasa tidak nyaman. 


\section{Instrumen}

Terdapat tiga instrumen yang digunakan pada penelitian ini. Pertama, yaitu State Trait Anxiety Inventory (STAI). STAI merupakan instrumen dengan property psikometri yang baik. STAI skala state memiliki properti psikometri yang baik dengan reliabilitas 0,89 untuk sampel non klinis (Balsamo dkk., 2013). Terdapat dua subskala yaitu skala yang mengukur kecemasan sebagai trait dan kecemasan sebagai state. Instrumen terdiri atas 40 aitem (20 aitem untuk skala state dan 20 aitem untuk skala trait). Instrumen menggunakan skala likert dari 1 hingga 4. 1= hampir tidak pernah, $4=$ hampir selalu. Semakin tinggi skor menunjukkan tingkat cemas yang semakin tinggi. Pada penelitian ini, peneliti hanya menggunakan skala kecemasan sebagai state.

Kedua, Positive Affect Negative Affect Scale (PANAS). PANAS berbentuk self-report yang mengukur tingkat terjadinya afek positif dan afek negatif dalam suatu waktu (Watson, Clark, \& Tellegen, 1988). Terdapat 20 aitem yang berisi afek positif dan afek negatif dijadikan sebagai aitem pada alat ukur ini. Terkait waktu yang dipilih, dapat dipilih "pada saat ini", "hari ini", "beberapa hari yang lalu", "beberapa minggu lalu", "tahun lalu", dan "secara umum. Paritisipan diminta menilai mood mereka dari angka 1-6. Angka satu mengindikasikan partisipan merasakan suatu perasaan dalam tingkat sangat kecil atau tidak sama sekali hingga angka enam mengindikasikan partisipan merasakan suatu perasaan dalam tingkat sangat besar. PANAS memiliki nilai reliabilitas sebesar 0,90 dan memiliki properti psikometri yang baik dalam mengukur afek.

Kemudian, Rosenberg Self Esteem

Scale (RSES) yang dikembangkan oleh Morris Rosenberg (1965). Alat ukur ini berbentuk self report dan berbentuk skala likert yang terdiri atas 10 aitem dan mengukur self esteem secara umum Rosenberg. Dari 10 aitem tersebut, terbagi atas dua bagian, yaitu lima aitem yang menggambarkan self esteem secara positif dan lima aitem yang menggambarkan selfesteem secara negatif. Adapun respon skala likert berdasarkan 4 skala dimana $1=$ tidak sesuai dan $4=$ sangat sesuai. Semakin tinggi skor, semakin tinggi self esteem. Adapun nilai reliabilitas alpha yaitu 0,90 dan dan validitas menggunakan aitem total correlation dengan nilai antara 0,32-0,82.

\section{Setting dan Peralatan}

Sesi dilakukan secara daring dengan menggunakan aplikasi zoom. Fasilitator menyiapkan handout beserta lembar latihan untuk membantu partisipan memahami materi. Pada saat sesi handout ditayangkan melalui fitur share screen yang terdapat pada aplikasi.

\section{Prosedur}

Partisipan diperoleh melalui penjaringan yang disebarkan melalui media sosial. Informasi yang disebarkan dilengkapi dengan link online yang dapat diisi oleh calon partisipan. Pada link tersebut dilengkapi dengan alat ukur State Trait Anxiety Inventory (STAI) untuk melihat tingkat kecemasan mahasiswa. Mahasiswa yang bersedia mengikuti terapi kelompok diarahkan untuk mengisi aitem-aitem STAI dan dilihat total skor berdasarkan skala trait dan state. Mahasiswa yang dipilih adalah mahasiswa dengan nilai pada skala state $\geq 40$.

Peneliti mewawancarai partisipan untuk mendapatkan gambaran mengenai self-esteem mereka dan kecenderungan mudah mengalami rasa cemas karena membandingkan diri dengan orang lain. Partisipan juga diberikan kuesioner Positive Affect Negative Affect (PANAS) dan Rosenberg Self Esteem Scale (RSES). Setelah itu terjaring tujuh orang partisipan. Meski demikian, sebelum diadakan pra-sesi, satu orang memutuskan untuk berhenti sehingga tersisa enam partisipan.

Pelaksanaan sesi terapi kelompok akan dilakukan sebanyak enam sesi dan satu kali pra-sesi serta satu kali sesi follow up yang dilakukan dua minggu setelah semua sesi selesai. Alat ukur yang digunakan pada 
penelitian ini yaitu STAI skala state, RSES, dan PANAS.

\section{Rancangan Program Intervensi}

Program intervensi berlangsung sebanyak enam sesi yang berlangsung sekitar 90-110 menit. Modul CBT diadaptasi dari modul yang disusun oleh Lenz (2018). Sesi pertama merupakan sesi untuk saling mengenal dan saling berbagi mengenai pengalaman yang tidak menyenangkan dan dampaknya karena dipicu oleh membandingkan diri dengan orang lain. Diharapkan partisipan dapat saling menunjukkan empati dan merasa bahwa dirinya tidak sendiri dalam menghadapi masalah. Selain itu, partisipan diberikan psikoedukasi mengenai dinamika munculnya rasa cemas dan informasi dasar terkait dengan CBT.

Sesi dua melatih partisipan untuk terbiasa mengidentifikasi emosi dan sensasi fisik saat dihadapkan pada situasi spesifik. Diharapkan partisipan terbiasa untuk mengidentifikasi bahwa suatu emosi biasanya muncul pada situasi tertentu.

Sesi tiga bertujuan untuk mengajak partisipan untuk mengidentifikasi pikiran negatif yang otomatis yang biasanya muncul dalam jebakan pikiran (thinking trap).
Dengan mengidentifikasi thinking trap, partisipan dapat menyadari bahwa pikiran tersebut yang pada dasarnya berpengaruh terhadap emosi. Setelah itu, partisipan diajarkan untuk membuat pikiran alternatif untuk menetralkan emosi negatif.

Sesi empat partisipan dilatih untuk menantang pikiran-pikiran negatif yang muncul dengan mengajukan pertanyaanpertanyaan kritis. Selain itu, partisipan juga dilatih untuk mencari bukti-bukti baik yang mendukung dan yang tidak mendukung dari pikiran negatif tersebut.

Sesi lima, partisipan dilatih untuk menguraikan suatu permasalahan secara lebih detail. Dengan begitu, meskipun berada pada situasi cemas, partisipan dapat berpikir secara objektif dengan melakukan suatu tindakan pemecahan masalah.

Sesi enam, merupakan sesi reviu dan menanyakan tilikan dan refleksi diri selama mengikuti sesi terapi kelompok.

\section{Teknik Analisis Data}

Data dianalisis dengan menggunakan analisis statistik dekriptif dan juga secara kualitatif.

\section{Gambar 1}

\section{Diagram Kecemasan}

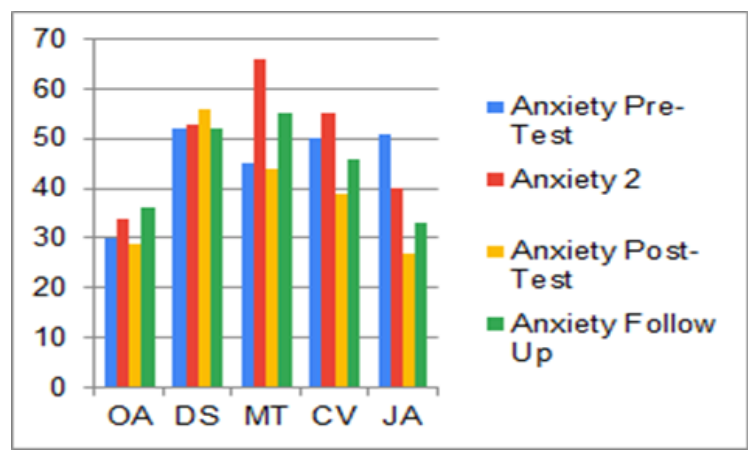

\section{ANALISIS DAN HASIL}

Hasil intervensi, dipaparkan dalam bentuk diagram batang sebagaimana pada gambar 1, yang menunjukkan terdapat perubahan kecemasan yang berbeda-beda antar partisipan. Secara umum terdapat perubahan yang fluktuatif pada skor kecemasan pada partisipan. Sebagian peserta mengalami penurunan skor pada saat posttest dan hanya partisipan JA yang menunjukkan penurunan secara konsisten dari pre-test hingga post-test. Berdasarkan 
pada hasil tersebut, CBT kelompok berbasis internet dapat mengurangi simtom kecemasan yang diukur dengan menggunakan STAI pada skala state pada empat orang partisipan. Meskipun demikian, pada saat sesi follow up pada empat orang partisipan (OA, MT, CV dan JA) mengalami kenaikan beberapa poin skor pada skala kecemasan. Hal ini dapat dipengaruhi oleh kondisi sulit yang dialami oleh partisipan pada saat follow up diambil. Pada partisipan DS terdapat kenaikan kecemasan dari asesmen pertama hingga follow-up. Skor yang cenderung tinggi, mengindikasikan bahwa DS memiliki trait cemas yang cukup tinggi.

Gambar 2

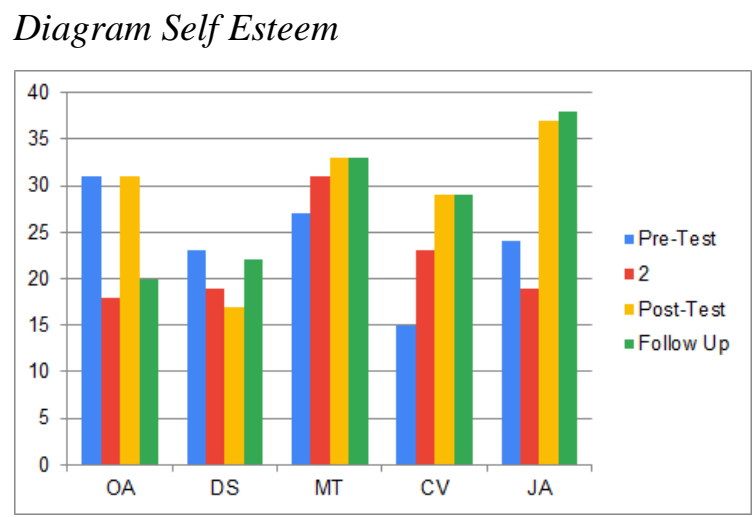

Pada pengukuran self esteem, terdapat peningkatan pada self-esteem, terutama pada tiga orang partisipan (MT, CV dan JA). Pada ketiga partisipan, peningkatan self-esteem tampak konsisten bahkan setelah dilakukan follow up.

Gambar 3

Diagram Positive Affect Negative Affect (PANAS)

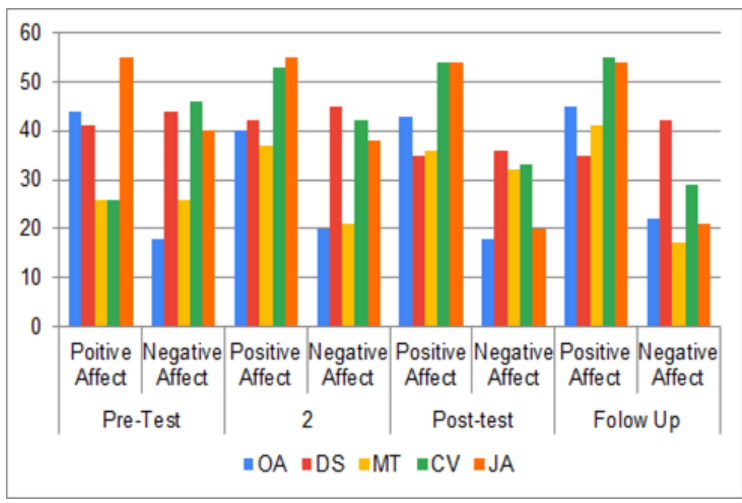

Jika dikaitkan dengan diagram self esteem terdapat hubungan terbalik yang sesuai dengan teori dimana saat kecemasan meningkat maka akan terjadi penurunan pada self esteem. DS mengalami penurunan self esteem dibandingkan dengan pengukuran pertama. Partisipan DS yang mengalami peningkatan skor kecemasan pada saat post-test beberapa poin dibandingkan pre-test. Hal ini juga berdampak pada menurunnya skala self esteem. Pada dasarnya DS memiliki skor kecemasan yang lebih tinggi dibandingkan dengan peserta lain. Hal ini didukung dengan hasil pengukuran emosi dengan PANAS tampak bahwa DS didominasi oleh afek negatif. Meskipun demikian, DS mengalami kenaikan self esteem pada sesi 
follow up seiring dengan menurunnya skor kecemasan pada saat sesi follow up. Pada partisipan OA, skor self esteem menunjukkan peningkatan dibandingkan dengan pengukuran kedua. Kemungkinan terdapat perubahan pada ranah kognitif. Akan tetapi, pada saat follow up terjadi penurunan skor, seiring dengan meningkatnya skor state kecemasan.

Secara umum, terdapat peningkatan self esteem pada tiga partisipan (MT, CV, dan JA) seiring dengan menurunnya kecemasan. Berdasarkan pada pengukuran emosi, partisipan yang mengalami

Tabel 1

\section{Hasil Wawancara Partisipan}

penurunan kecemasan dan kenaikan selfesteem cenderung memiliki emosi positif yang lebih tinggi dibandingkan dengan emosi negatif terutama pada pada saat post test dan follow up.

Secara kualitatif partisipan melaporkan adanya perubahan setelah mengikuti sesi. Semua partisipan merasakan adanya perubahan yang lebih positif dalam memandang diri mereka sendiri. Selain itu, mereka juga melihat dari berbagai sisi sehingga tidak terpaku pada pikiran negatif saja.

\section{Partisipan Hasil Wawancara}

JA JA mengungkapkan bahwa sebelumnya ia berpikir bahwa dirinya merupakan seorang yang gagal. Namun, sekarang ia merasa lebih termotivasi untuk mengembangkan dirinya.

OA OA menyadari bahwa selama ini ia terpaku pada hal negatif dari dirinya saja. berpikir bahwa dirinya tidak seburuk yang ia bayangkan sebelumnya.

$\mathrm{CV} \quad \mathrm{CV}$ menyatakan meskipun perasaan sedih tidak bisa dihilangkan saat membandingkan diri, namun ia mulai menyadari pikiran negatifnya tidak selalu benar. Setelah mengikuti sesi ia menyadari bahwa dirinya tidak harus selalu menyamai orang lain.

MT MT menyatakan bahwa perbedaan yg muncul akibat membandingkan diri merupakan hal yg wajar. Ia mulai melihat bahwa setiap orang mengalami pengalaman yang berbeda begitupun dengan dirinya. Dengan memiliki pikiran tersebut ia menjadi lebih menghargai pencapaiannya sendiri.

DS

Hingga saat ini DS masih merasa iri dan merasa orang lain lebih sukses dibandingkan dirinya. Meskipun demikian ia mulai bisa melakukan hal-hal yang dapat mengurangi rasa tidak nyaman tersebut mengubah perilakunya untuk meminimalisir penggunaan media sosial

Berdasarkan pada pemaparan diatas, dapat disimpulkan bahwa terdapat perubahan pada pola berpikir partisipan setelah mengikuti sesi CBT dimana terdapat peningkatan cara berpikir yang lebih adaptif dalam memandang diri. Secara kuantitatif, 
intervensi CBT dapat meningkatkan self esteem terutama pada tiga orang partisipan. Meskipun pada dasarnya simtom kecemasan tidak berkurang secara signifikan, hal ini cukup wajar, karena cemas merupakan respon adaptif untuk menghadapi situasi yang mengancam di masa yang akan datang. Hal ini diikuti dengan pola berpikir yang adaptif ini juga berdampak pada pengukuran afek dimana terdapat peningkatan pada afek positif dan menurunnya afek negatif. Meskipun penurunan skor self-esteem tidak konsisten pada partisipan, namun berdasarkan pada hasil kualitatif mereka melaporkan perubahan yang cenderung positif terutama dari segi kognitif. Meskipun rasa cemas karena membandingkan diri masih ada, namun perubahan pola pikir menciptakan sudut pandang yang lebih baru dan lebih adaptif terhadap diri mereka.

\section{DISKUSI}

Berdasarkan pada hasil kuantitatif diperoleh hasil bahwa terdapat penurunan skor kecemasan pada sebagian besar partisipan yang juga diikuti dengan peningkatan self esteem. Hal ini menunjukkan bahwa terapi kelompok dengan menggunakan pendekatan CBT dianggap efektif dalam meningkatkan self esteem pada mahasiswa yang mengalami kecemasan akibat membandingkan diri dengan orang lain. Sejalan penelitian yang dilakukan oleh Soraya (2016) yang menunjukkan bahwa CBT kelompok dapat meningkatkan keberhargaan diri seseorang yang diiringi dengan perubahan dalam pola pikir. Hal ini juga didukung oleh karakteristik yang dimiliki oleh partisipan sendiri dimana mereka memiliki motivasi internal dalam mengikuti sesi dan adanya keinginan untuk berubah.

Meskipun demikian, pada saat pengukuran dilaksanakan terdapat fluktuasi skor kecemasan dimana terdapat peningkatan pada pengukuran kedua. Kemungkinan besar hal ini disebabkan oleh kondisi lain yang dialami oleh partisipan seperti pandemi COVID 19 yang sedang melanda ataupun kondisi keluarga.
Penelitian yang dilakukan oleh Cao dkk. (2020) terdapat peningkatan kecemasan pada kehidupan sehari-hari dan saat pandemi COVID 19 berlangsung. Di samping itu, kebijakan untuk membatasi interaksi secara langsung, membatasi diri keluar rumah, kekhawatiran terhadap performa akademik menjadi sumber stres yang berdampak pada rasa peningkatan rasa cemas (Son, Hedge, Smith, Wang, \& Sasangohar, 2020).

Selain itu faktor sulit yang juga dialami oleh partisipan adalah terkait dengan orang tua. Pada DS orang tua berperan kuat dalam munculnya pikiran negatif terhadap dirinya. Pada saat sesi katarsis seringkali mereka mengungkapkan bahwa yang membuat ia seringkali membandingkan diri adalah orang tua. Karakteristik orang tua yang cenderung mengkritik berkontribusi terhadap self esteem yang negatif. Sejalan dengan Harter (1993) yang menyatakan bahwa penilaian orang tua dan sosok yang dianggap otoritas sangat berpengaruh terhadap terbentuknya self esteem yang baik. Pola asuh orang tua memiliki pengaruh terhadap pola berpikir dan cara memandang diri. Segrin, Woszidlo, Givertz dan Montgomery (2013) mengungkapkan orang tua yang cenderung mengontrol diasosiasikan berkembangnya trait anxiety pada anak. Individu yang mempersepsi orang tua sebagai figur otoriter akan merasakan tuntutan dari orang tua sebagai beban dan mengembangkan sikap perfeksionis yang tidak adaptif. Akibatnya, akan membentuk evaluasi diri yang negatif (Soysa \& Weiss, 2013). Hal ini juga didukung oleh kondisi saat ini dimana peserta lebih banyak menghabiskan waktu di rumah karena masa libur semester dan kondisi pandemi sehingga menyebabkan munculnya masalah baru..

Pada partisipan yang tidak mengalami peningkatan self-esteem (OA) kemungkinan besar hal ini disebabkan oleh penggunaan media sosial yang tergolong aktif. Hal ini kemungkinan besar berpengaruh pada self esteem. Berdasarkan pada penelitian yang dilakukan oleh Vogel, Rose, Okdie, Eckles, dan Franz (2015), 
individu yang sering mengakses media sosial dan mengakses profil orang lain akan cenderung melakukan komparasi sosial sehingga berdampak pada menurunnya self esteem. Hal ini disebabkan oleh sosial media cenderung memfasilitasi seseorang untuk membangun profil yang positif mengenai dirinya sehingga individu yang sering mengakses media sosial cenderung mengalami perasaan cemas karena sensitif atas penilaian orang lain (Woods \& Scott, 2018). Walaupun begitu, pada dasarnya kecemasan yang dimiliki oleh OA tidak tergolong tinggi sehingga skor self esteem masih berada di atas nilai tengah yaitu 20 .

Adapun keterbatasan pada penelitian ini antara lain sampel yang direkrut hanya terbatas pada mahasiswa Universitas $X$ dan sebagian besar merupakan mahasiswa psikologi. Perlu adanya pengujian yang lebih lanjut untuk cakupan yang lebih luas dari berbagai latar belakang pendidikan. Di samping itu, pada sebaiknya juga dilakukan pengukuran dengan instrumen social comparison sehingga peneliti memperoleh data mengenai tingkat self comparasion yang ada pada partisipan. adalah cakupan komparasi sosial yang cukup beragam antar partisipan sehingga pembahasan yang cenderung luas. Selain itu, sebaiknya ditambahkan pengukuran mengenai trait dari kecemasan sehingga dapat memberikan penjelasan yang lebih menyeluruh mengenai gambaran cemas yang dimiliki oleh partisipan.

\section{SIMPULAN}

Berdasarkan pada hasil diperoleh dalam penelitian ini diperoleh kesimpulan bahwa secara kuantitatif CBT kelompok berbasis daring efektif dapat meningkatkan self esteem pada tiga orang partisipan yang diikuti dengan penurunan pada gejala cemas. Di sisi lain, hasil analisis kualitatif menunjukkan bahwa semua partisipan melaporkan terdapat perubahan pada cara pandang terhadap suatu masalah menjadi lebih adaptif dibandingkan sebelum mengikuti terapi. Di samping itu partisipan juga melaporkan bahwa mereka dapat menerima diri mereka dibandingkan sebelumnya.

\section{SARAN}

Berdasarkan pada temuan yang diperoleh dari penelitian ini menunjukkan bahwa CBT kelompok berbasis daring sangat mungkin diterapkan dan dapat membantu individu terutama yang memiliki kendala jarak. Meskipun demikian perlu ada perbaikan dan fokus perhatian dalam pelaksanaan terapi berbasis daring.

Secara metodologis, sebaiknya dilakukan perhitungan statistik lanjut seperti uji beda kelompok untuk melihat signifikansi dari hasil. Selain itu, metode penelitian randomized control trial (RCT) sangat mungkin dilakukan untuk melihat efektivitas penggunaan daring dengan kontrol yang lebih ketat.

Penerapan intervensi kelompok secara daring dapat menjadi media yang menjanjikan di masa yang akan datang, namun perlu diperhatikan mengenai stabilitas koneksi dan mendorong adanya interaksi yang lebih interaktif dengan menggunakan berbagai aplikasi seperti mentimeter, games dan sebagainya. Sebaiknya ditambahkan pengukuran mengenai trait kecemasan partisipan sehingga lebih memberikan gambaran mengenai pola berpikir partisipan. 


\section{DAFTAR PUSTAKA}

American College Health Association. (2018). Undergraduate reference group executive summary. Diakses dari https://www.acha.org/documents/ncha/ NCHA-

II_Fall_2018_Undergraduate_Referenc e_Group_Executive_Summary.pdf.

Aspinwall, L. G., \& Taylor, S. E. (1993). Effects of social comparison direction, threat, and self-esteem on affect, selfevaluation, and expected success. Journal of personality and social psychology, 64(5), 708-722.

Balsamo, M., Romanelli, R., Innamorati, M., Ciccarese, G., Carlucci, L., \& Saggino, A. (2013). The state-trait anxiety inventory: shadows and lights on its construct validity. Journal of Psychopathology and Behavioral Assessment, 35(4), 475-486.

Barak, A., Hen, L., Boniel-Nissim, M., \& Shapira, N. A. (2008). A comprehensive review and a meta-analysis of the effectiveness of internet-based psychotherapeutic interventions. Journal of Technology in Human Services, 26(2-4), 109-160.

Beiter, R., Nash, R., Mccrady, M., Rhoades, D., Linscomb, M., Clarahan, M., \& S. Sammut. (2014). The prevalence and correlates of depression, anxiety, and stress in a sample of college students. $J$ Affect Discord, 173, 90-96.

Boston University. (2016). Anxiety the most common mental health diagnosis in college students. Diakses dari http://www.bu.edu/articles/2016/colleg e-students-anxiety-and-depression/.

Butzer, B., \& Kuiper, N. A. (2006). Relationships between the frequency of social comparisons and self-concept clarity, intolerance of uncertainty, anxiety, and depression. Personality and Individual Differences, 41(1), 167176.
Cao, W., Fang, Z., Hou, G., Han, M., Xu, X., Dong, J., \& Zheng, J. (2020). The psychological impact of the COVID-19 epidemic on college students in China. Psychiatry Research, 287, 112934.

Festinger, L. (1954). A theory of social comparison processes. Human Relations, 7(2), 117-140.

Gilbert, P., \& Miles, J. N. (2000). Sensitivity to Social Put-Down: It's relationship to perceptions of social rank, shame, social anxiety, depression, anger and selfother blame. Personality and Individual Differences, 29(4), 757-774

Harter, S. (1993). Causes and consequences of low self-esteem in children and adolescents. In R. Baumeister (Ed.), Self esteem: The puzzle of low self regard (pp. 87-116). Springer.

Kring, A., Johnson, S., Davidson, G. \& Neale, J. (2012). Abnormal psychology (12th ed.).Wiley

Kumar, V., Sattar, Y., Bseiso, A., Khan, S., \& Rutkofsky, I. H. (2017). The effectiveness of internet-based cognitive behavioral therapy in treatment of psychiatric disorders. Cureus, 9(8), e1626.

Lenz, A. S. (2018). Cognitive behavioral therapy for anxiety: Application of the F.E.A.R. model for adults. Diakses dari https://medicine.umich.edu/dept/psychi atry/programs/anxiety-disordersprogram-adult/patient-resources.

Mahmoud, J. S. R., Staten, R. T., Hall, L. A., \& Lennie, T. A. (2012). The relationship among young adult college students' depression, anxiety, stress, demographics, life satisfaction, and coping styles. Issues in Mental Health Nursing, 33(3), 149-156.

Mellalieu, S. D., Hanton, S., \& Jones, G. (2003). Emotional labeling and competitive anxiety in preparation and competition. The Sport Psychologist, 17(2), 157-174. 
Micari, M., \& Drane, D. (2011). Intimidation in small learning groups: The roles of social-comparison concern, comfort, and individual characteristics in student academic outcomes. Active Learning in Higher Education, 12(3), 175-187.

Micari, M., \& Pazos, P. (2014). Worrying about what others think: A socialcomparison concern intervention in small learning groups. Active Learning in Higher Education, 15(3), 249-262.

Regehr, C., Glancy, D., \& Pitts, A. (2013). Interventions to reduce stress in university students: A review and metaanalysis. Journal of Affective Disorders, 148(1), 1-11.

Kementrian Kesehatan RI. (2018). Laporan nasional riset kesehatan dasar 2018. Diakses dari http://labdata.litbang.kemkes.go.id/ima ges/download/laporan/RKD/2018/Lapo ran_Nasional_RKD2018_FINAL.pdf.

Segrin, C., Woszidlo, A., Givertz, M., \& Montgomery, N. (2013). Parent and child traits associated with overparenting. Journal of Social and Clinical Psychology, 32(6), 569-595.

Son, C., Hegde, S., Smith, A., Wang, X., \& Sasangohar, F. (2020). Effects of COVID-19 on college students' mental health in the United States: Interview survey study. Journal of Medical Internet Research, 22(9), e21279.

Soraya, T.I. (2016). Efektivitas cognitive behavioral therapy (CBT) dalam meningkatkan self-esteem pada dewasa muda dengan self-esteem negatif [Tugas Akhir Magister Profesi Psikologi Klinis Dewasa Tidak Diterbitkan]. Universitas Indonesia.

Sowislo, J. F., \& Orth, U. (2013). Does low self-esteem predict depression and anxiety? A meta-analysis of longitudinal studies. Psychological Bulletin, 139(1), 213-240.
Soysa, C. K., \& Weiss, A. (2014). Mediating perceived parenting styles-test anxiety relationships: Academic procrastination and maladaptive perfectionism. Learning and Individual Differences, $34,77-85$.

Vogel, E. A., Rose, J. P., Okdie, B. M., Eckles, K., \& Franz, B. (2015). Who compares and despairs? The effect of social comparison orientation on social media use and its outcomes. Personality and Individual Differences, 86, 249256.

Watson, D., Clark, L. A., \& Tellegen, A. (1988). Development and validation of brief measures of positive and negative affect: the PANAS scales. Journal of personality and social psychology, 54(6), 1063.

Westbrook, D., Kennerley,H., \& Kirk, J. (2011). An introduction to cognitive behaviour therapy: Skills and applications. SAGE.

Wheeler, L., \& Miyake, K. (1992). Social comparison in everyday life. Journal of Personality and Social Psychology, 62(5), 760-773.

Woods, H. C., \& Scott, H. (2016). \# Sleepyteens: Social media use in adolescence is associated with poor sleep quality, anxiety, depression and low self-esteem. Journal of Adolescence, 51, 41-49. 